УДК 656.222.1

\title{
АНАЛІЗ ОСНОВНИХ ПРОБЛЕМ ПРИ ПЕРЕВЕЗЕННІ МАСОВИХ ВАНТАЖІВ ЗАЛІЗНИЧНИМ ТРАНСПОРТОМ
}

К-т техн. наук А.Л. Обухова, магістранти М.С. Шевельова, Н.О. Стешенко

\section{АНАЛИЗ ОСНОВНЫХ ПРОБЛЕМ ПРИ ПЕРЕВОЗКЕ МАССОВЫХ ГРУЗОВ ЖЕЛЕЗНОДОРОЖНЫМ ТРАНСПОРТОМ}

\author{
К-т техн. наук А.Л. Обухова, магистранты М.С. Шевелёва, Н.А. Стешенко
}

ANALYSIS OF THE MAIN PROBLEMS IN BULK TRANSPORT BY R

Cand. of techn. sciences. A. Obukhova, master student M. Shevelova, N.A. Steshenko

В статті, на основі наведеної статистики, визначена доля масових вантажів, які перевозяться залізнииями Украӥни, особливості умов утворення вантажопотоків масових вантажів. Також визначені найбільш актуальні проблеми пов'язані з перевезенням масових вантажів $і$ запропоновані шляхи їх вирімення, з урахуванням вимог сучасних інформаційних $i$ транспортних технологій.

Ключові слова: масовий вантаж, маршрутне відправлення, порожній вагон, тариф.

В статье, на основании приведенной статистики, определена доля массовых грузов перевозимых железными дорогами Украины, особенности условий образований грузопотоков массовых грузов. Также определены наиболее актуальныле проблемы, связанные с перевозкой массовых грузов и предложены пути их решения, с учетом требований современных информачионных и транспортных технологий.

Ключевые слова: массовый груз, маршрутная отправка, порожний вагон, тариф.

When transporting bulk cargo by rail raises a number of issues that will melt on the way optimal performance industrial and transportation systems. In this paper, based on the above statistics, the proportion determined bulk transported by railways of Ukraine, especially the conditions of formation of cargo flows of bulk. Also identified the most pressing problems related to the carriage in bulk, and ways to solve them, to meet the requirements of modern information and transportation technologies. The analysis of the shortcomings of the method of forming routes for the carriage of bulk: Timely provision of supply of empty wagons, rational use of the park empty wagons, tariffs in organizing the route deliveries.

Keywords: bulk cargo, full train, empty wagon, tariff.

Вступ. Залізничний транспорт України є невід'ємною ланкою в стабільній та безперервній роботі промислових галузей країни, забезпечує внутрішні та зовнішні транспортно-економічні зв'язки. Наявні технологічні процеси роботи підприємств промислових галузей утворюють як вхідні (сировина для потреб підприємства) так і вихідні (продукція підприємства) потоки масових вантажів освоєння яких покладено на залізничний транспорт [10].

Постановка проблеми. При перевезенні масових вантажів залізницею виникає ціла низка проблем, що встає на перешкоді оптимальній роботі транспортно- промислової системи. Ці проблеми вимагають вирішення сучасними методами, задля збереження конкурентоспроможності та підвищення інвестиційної привабливості залізничного транспортну на ринку транспортних послуг.

Аналіз останніх досліджень і публікацій. Проблемі маршрутизації значне місце приділено у працях В.М. Акулінічева та Н.Е. Борового. В [1, 3] ефективність маршрутизації проявляється у зіставленні їі 3 немаршрутним відправленням вантажів, у зв'язку з цим до неї включають тільки ті збереження та втрати, які відрізняються при цих способах організації вагонопотоків. У 
цих випадках маршрутизація економічно доцільна, якщо збереження більше втрат i економічний ефект виражається різницею цих двох величин.

Визначення мети та задачі дослідження. Метою дослідження $\epsilon$ виявлення та аналіз основних загальних проблем перевезення масових вантажів на залізницях України, пошук та опис шляхів та методик їх вирішення.

Основна частина дослідження. Незважаючи на зменшення обсягів перевезень у внутрішньому сполученні, перевезено 182,6 млн тонн, імпортні перевезення становлять 36,2 млн тонн, експортні - 141,3 млн тонн, транзитні - 29,5 мЛн тонн [9].

Переважну частку номенклатурних груп, що перевозяться залізницями України складають такі вантажі як: мінеральні добрива, будівельні матеріали, кам'яне вугілля та руди, зокрема залізні. Важливе місце займають також різноманітні метали і нафтові вантажі [5]. Відсоткове співвідношення номенклатурних груп наведене у табл. 1

Таблиця 1

Перелік номенклатурних груп та вантажів, що перевозяться залізничним транспортом

\begin{tabular}{|l|c|c|}
\hline \multicolumn{1}{|c|}{ Найменування вантажу } & $\begin{array}{c}\text { Відсоток в обсязі } \\
\text { перевезень }\end{array}$ & Спосіб перевезення \\
\hline 1. Кам'яне вугілля & 27,0 & Навалом \\
\hline 2. Руда залізна та марганцева & 18,1 & Навалом \\
\hline 3. Мінбудматеріали & 15,1 & Навалом \\
\hline 4. Чорні метали & 9,3 & Навалом \\
\hline 5. Нафта та нафтопродукти & 6,8 & Наливом \\
\hline 6. Зерно та продукти мелення & 2,6 & Насипом \\
\hline 7. Хімічні та мінеральні добрива & 2,6 & Навалом \\
\hline 8. Кокс & 2,6 & Навалом \\
\hline 9. Хімікати & 2,2 & по-різному \\
\hline 10. Брухт чорних металів & 2,1 & Навалом \\
\hline 11. Цемент & 1,2 & Навалом \\
\hline 12. Руда кольорових металів & 1,0 & Навалом \\
\hline 13. Лісні вантажі & 0,6 & Навалом \\
\hline 14. Машини та обладнання & 0,1 & по-різному \\
\hline 15. Кольорові метали і вироби & 0,1 & Навалом \\
\hline 16. Гнші вантажі & 8,6 & по-різному \\
\hline
\end{tabular}

Згідно з табл. 1 майже 85 \% обсягу перевезень - це вантажі перших восьми найменувань. Приблизно $80 \%$ вантажів перевозять навалом (без рахунку місць) у відкритому рухомому складі, близько $7 \%$ наливом у цистернах, $3 \%$ - насипом у закритому рухомому складі, а решту $10 \%-$ різними, у тому числі й названими вище способами [7].

Основними вантажоформуючими підприємствами $є$ представники добувної, хімічної, машинобудівної та металургічної промисловості що користуються послугами приватних залізничних операторів та операторів, що входять до структури «Укрзалізниці».

До основних проблем при перевезенні масових вантажів можна віднести: економічну недосконалість маршрутних відправок; неефективне використання порожніх вагонопотоків, для забезпечення освоєння заявлених обсягів; забезпечення схоронності перевезень масових вантажів у прямому та міждержавному сполученнях, затримка вантажовідправником (вантажоодержувачем) рухомого складу та інші фактори.

Однією 3 переваг перевезень масових вантажів $\epsilon$ можливість формування 
маршрутних відправок. Але метод маршрутизації перевезень має як переваги, так i недоліки. Зокрема, в «Інструктивних вказівках 3 організації вагонопотоків на залізницях України» [6] говориться, що достатньою для включення в план маршрутизації окремої кореспонденції вантажів є така умова: додаткові витрати на організацію маршрутів, порівняно 3 немаршрутним відправленням на станції навантаження $\Delta E_{c н(i j)} \mathrm{i}$, якщо маршрути прямі, також на станції вивантаження $\Delta E_{c в(i j)}$, не повинні перевищувати економії на шляху $\Delta E_{\text {јек }}$ пря (ij прямування) за кожним $j$-м призначенням 3 потужністю вагонопотоку $i$, що визначається за формулою

$$
\Delta E_{c н(i j)}+\Delta E_{c в(i j)} \leq \Delta E_{\text {ек(ij) }}^{\text {прям }}
$$

Раніше зацікавленість вантажовласників i залізниці в частині маршрутизації вагонопотоків об’єднувались планом перевезень та планом маршрутизації навантаження як його основної складової. Але ж на даному етапі існують протиріччя між інтересами залізниць, вантажовідправниками та операторамивласниками вантажних вагонів. Наприклад, якщо Укрзалізниці у цілому вигідно формувати відправницькі маршрути і 3 технологічної, і з економічної точки зору, то залізниця відправлення маршруту недоотримує доходи, оскільки поправковий коефіцієнт до базового тарифу передбачає зменшення провізних платежів при маршрутизації у порівнянні 3 тарифом за вагонні відправки, а механізму перерозподілу між залізницями експлуатаційних витрат та економії, що виникає на шляху прямування через скорочення переробки вагонів на технічних станціях, немає. Звідси і прагнення залізниць відправлення маршрутів оформити перевізні документи на вантажі, що прямують маршрутами, як на вагонні відправки. Отже економічна ефективність маршрутизації для залізниці, 3 огляду на тарифні умови, можлива тільки при певному обсязі добового вантажообігу. у [2] запропоновано компенсувати витрати залізниці за рахунок додаткового доходу від формування маршрутних відправок на коліях загального користування.

$$
D_{\partial о д}{ }^{\prime}=e_{\text {форм }} \cdot Q_{м}
$$

де $e_{\text {форм }}$ - ставка збору за формування відправницьких маршрутів на коліях загального користування силами та засобами залізниці, грн/т;

$$
Q_{м}{ }^{\text {нетто }} \text { - вага маршруту нетто, т. }
$$

Процес підвищення рівня доставки вантажів можливий за рахунок зменшення кількості переробок вагонів при виконанні місцевої роботи. Це можна досягнути при більш широкому використанні маршрутизації - як відправницької, так i ступінчатої, що, у свою чергу, досягається оптимальною організацією місцевої роботи сумісно з оперативним плануванням або при календарному навантаженні вантажовідправниками груп вагонів, а також при взаємодії всіх підрозділів, що беруть участь у перевізному процесі.

Окремим недоліком маршрутизації при перевезенні масових вантажів постає неефективне використання парку порожніх вагонів. В сучасних економічних та ринкових умовах, в умовах значної присутності вагонів власності приватних залізничних операторів на ринку, значна їх кількість рухається по кільцевим маршрутам [4]. Використання кільцевих маршрутів призводить до збільшення коефіцієнту порожнього пробігу вагонів, i як наслідок погіршення основних кількісних та якісних показників роботи залізниці. До засобів зменшення значення порожнього пробігу, та підвищення економічної ефективності маршрутизації масових вантажів можна віднести:

- тарифне стимулювання маршрутних відправок порожніх вагонів;

- оптимізація кількості операторів по кожній великій навантажувальній станції;

- перехід від непереривного прийому заявок к місячному плануванню перевезень порожніх вагонів;

- застосування технології здвоєних операцій.

Основним ефектом від використання маршрутизації порожніх вагонопотоків $\epsilon$ збільшення маршрутної швидкості поїздів, що сприяє виконанню залізницею термінів 
доставки вантажів. Зокрема маршрутизація порожніх вагонопотоків сприяє:

вагонів; скороченню парку вантажних

- скороченню капітальних вкладень на розвиток парку вантажних вагонів;

- скороченню амортизаційних відрахувань на парк вантажних вагонів;

- скороченню витрат на переробку вагонопотоку на технічних станціях;

- скороченню кількості пошкоджень вагонів в результаті сортування на гірці та інше.

Також однією із поширених проблем в перевезеннях масових вантажів $є$ задача своєчасного забезпечення перевізниками, власниками рухомого складу, навантажувальними ресурсами, особливо його дефіцитним родом напіввагонів та іншими спеціальними вагонами. Проаналізувавши вагонний парк Укрзалізниці, можна визначити одну 3 причин, яка сприяла виникненню нестачі порожніх вагонів. Значна кількість підприємств, які користуються вагонами Укрзалізниці, не виконують норм, які відведені на навантажувальні операції. За даними Укрзалізниці, близько 35,9 \% вагонного парку стоїть на під'їзних коліях в очікуванні навантажувальних операцій, під обробкою на технічних станціях знаходиться близько $37,1 \%$, на проміжних станціях знаходиться близько $6 \%$ і всього $21,3 \%$ знаходяться у русі (рис. 1).
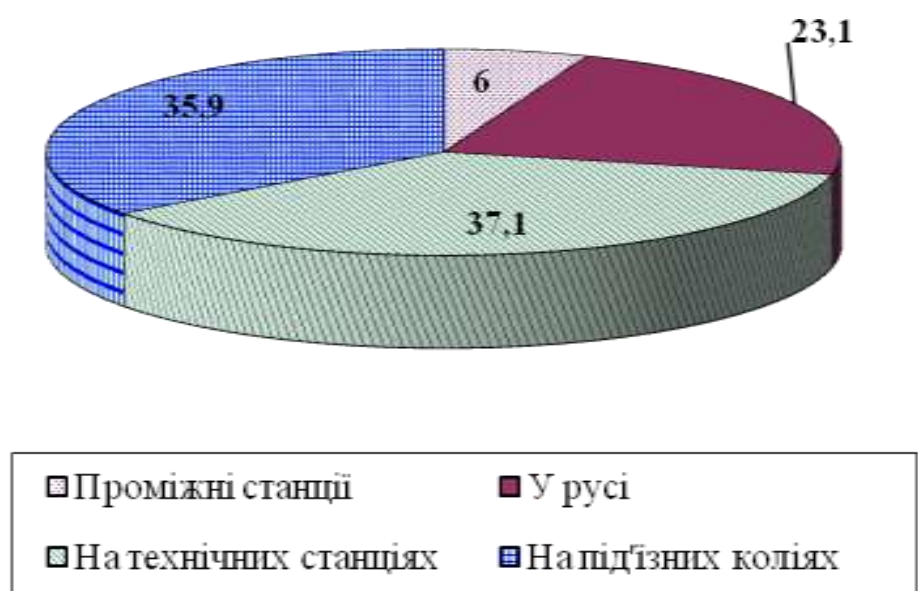

Рис. 1. Діаграма розподілу часу затримки вагонів

Уникнути виникнення подібних ситуацій можливо за рахунок удосконалення процесу перевезень 3 використанням нових інформаційно-керуючих систем, що призведе до оптимізації використання порожніх вагонів i, як наслідок, отримання зростання доходів залізниць та уникнення збитків через виплату штрафів [8].

\section{Висновки 3 дослідження i} перспективи, подальший розвиток у даному напрямку. При розгляді специфіки перевезень масових вантажів більш актуальними проблемами виявились маршрутизація вантажів, своєчасне забезпечення вантажовідправників порожніми вагонами у необхідних обсягах

та загалом неефективність використанні вагонного парку залізниць. А проблема забезпечення порожніми вагонами полягає в тому що, значна кількість вагонів які знаходяться на під’їзних коліях чекають виконання 3 ними операцій.

Крім того, недосконала тарифна політика викликає протиріччя між інтересами залізниць, вантажовідправниками та операторами-власниками вантажних вагонів, що також призводить до зменшення зацікавленості по відношенню до маршрутних відправок.

Одним 3 варіантів уникнення простоїв порожніх вагонів $є$ удосконалення процесу перевезень з використанням нових інформаційно-керуючих систем.

В статті наведено аналіз проблематики відправки масових вантажів. Однак враховуючи актуальність дане питання потребує подальшого дослідження та розгляду відповідно до отриманих висновків. 


\section{Список використаних джерел}

1. Акулиничев, В.М. Организация вагонопотоков и маршрутизация перевозок [Текст] / В.М. Акулиничев, О.С. Кирьянова, Н.Е. Боровой. - М.: Изд-во «Транспорт», 1970. $320 \mathrm{c}$.

2. Богомазова, Г.Є. Удосконалення методів визначення ефективності маршрутизації перевезень з урахуванням сучасних вимог [Текст] / Г.С. Богомазова // Збірник наукових праць Української державної академії залізничного транспорту . - 2013. - Вип. 137. - С. 105109.

3. Боровой, Н.Е. Маршрутизация перевозок грузов [Текст] / Н.Е. Боровой. - М.: Транспорт, 1978. - 216 с.

4. Верлан, А. І. Підвищення ефективності управління приватним вагонним парком за рахунок відправницької маршрутизації порожніх вагонопотоків [Текст] / А. І. Верлан, Д. М. Козаченко, Р. В. Вернигора // Залізн. трансп. України. - 2012. - № 6. - С. 35-37.

5. Железнодорожный транспорт Украины: характеристика отрасли [Електронний pecypc]. - Режим доступу: http://transportinform.com/rail-transportation/501-zheleznodorozhnyitransport-ukrainy.html.

6. Інструктивні вказівки з організації вагонопотоків на залізницях України [Текст]: наказ Укрзалізниці від 29.12.2004 р. № 1028-ЦЗ - К.: Вид-во ТОВ «Швидкий рух», 2005. $100 \mathrm{c}$.

7. Нестеренко, Г.І. Визначення параметрів вагонопотоків з навальними вантажами на залізницях України [Текст] / Г.І. Нестеренко // Вісник Академії митної служби України. Серія : Технічні науки. - 2014. - № 1. - С. 80-85.

8. Рибальченко, Л.І. Оптимізація використання порожніх вагонів в умовах дефіциту рухомого складу [Текст] / Л.І. Рибальченко, Д.В. Франковський // Збірник наукових праць Української державної академії залізничного транспорту . - 2014. - Вип. 145. - С. 69-73.

9. У грудні 2014 року Укрзалізниця перевезла 29,4 млн тонн вантажів [Електронний pecypc] // Офіційний сайт Міністерства інфраструктури України. - Режим доступу: http://www.mtu.gov.ua/ru/news/47330.html.

10. Укрзалізниця. Вантажні перевезення [Електронний ресурс]. - Режим доступу: http://uz.gov.ua/cargo_transportation/.

Рецензент д-р техн. наук, професор Д.В.Ломотько

\footnotetext{
Обухова Анна Леонідівна, канд. техн. наук, доиент кафедри управління вантажною $і$ комериійною роботою Украйнська державна академія залізничного транспорту. Тел.: (057) 730-10-85. E-mail: uvkr@kart.edu.ua

Шевельова Маріанна Сергївна, магістр, кафедра управління вантажною $і$ комериійною роботою Украӥнська державна академія залізничного транспорту. Тел.: (057) 730-10-85. E-mail: uvkr@kart.edu.ua

Стешенко Наталія Олександрівна, магістр, кафедра управління вантажною $і$ комериійною роботою Украйнська державна академія залізничного транспорту. Тел.: (057) 730-10-85. E-mail: uvkr@kart.edu.ua

Anna Obukhova, lecturer, department of Management of cargo and commercial work Ukrainian State Academy of Railway Transport.Tel.: (057) 730-10-85.E-mail: uvkr@kart.edu.ua

Shevelova Marianna, master, department of Management of cargo and commercial work Ukrainian State Academy of Railway Transport.Tel.: (057) 730-10-85. E-mail: uvkr@kart.edu.ua

Steshenko Nataliya, master, department of Management of cargo and commercial work Ukrainian State Academy of Railway Transport.Tel.: (057) 730-10-85.E-mail: uvkr@kart.edu.ua
} 